\title{
ANALYSIS OF PTKIN OPPORTUNITIES: QUALITY MEASUREMENT THROUGH THE MALCOLM BALDRIGE CRITERIA FOR USING THE WORLD CLASS UNIVERSTY
}

\author{
Ihwan Fauzi \\ Islamic Educational Management Department, Universitas Islam Negeri Sunan Kalijogo, \\ Yogyakarta, Indonesia \\ Email: ihwan.fauzi318@gmail.com
} DOI: http://doi.org/10.33650/al-tanzim.v5i1.1367

Received: August 2020 $\quad$ Accepted: March $2021 \quad$ Published: March 2021

\begin{abstract}
:
This study analyzes the opportunity for PTKIN to reach World Class University using criteria, especially at UIN Sunan Kalijaga Yogyakarta. The quality of an educational institution needs to be continuously improved (continuous improvement) to increase competitiveness. The research used a qualitative approach to the type of case study. Data collection techniques were carried out through; observation, interview and documentation. Furthermore, the research data is presented in a descriptive narrative form. The results of the study show that the accreditation is A (the highest score), but if it is measured or assessed by international standards EdPEx may only get a score in the interval 476 - 575, so that internationally it is categorized as a Good Performance University, yet it has NOT reached the World Class University. Improved by using a new standard to reach a world class university, Malcolm Baldrige is an international standard quality audit that is ready to fight the changing times. Malcolm Baldrige developed a flexible and creative approach in line with the needs of organization, especially the State Islamic Religious College.
\end{abstract}

Keywords: Quality improvement, Educational Institutions, Malcolm Baldrige Criteria

\begin{abstract}
Abstrak:
Penelitian ini menganalisis tentang peluang PTKIN mencapai World Class University menggunakan Kriteria khususnya di UIN Sunan Kalijaga Yogyakarta. Mutu suatu lembaga pendidikan perlu ditingkatkan secara berkelanjutan (continuous improvement) untuk meningkatkan daya saing. Peneliti menggunakan pendekatan kualitatif jenis studi kasus. Teknik pengumpulan datanya dilakukan melalui; observasi, wawancara dan dokumentasi. Selanjutnya data hasil penelitian disajikan dalam bentuk deskriptif naratif. Hasil Penelitian menunjukkan bahwa akreditasi A (Nilai tertinggi), tetapi apabila diukur atau dinilai dengan standar internasional EdPEx mungkin hanya mendapatkan skor di dalam interval 476 - 575, sehingga secara internasional dikategorikan sebagai Good Performance University saja BELUM mencapai World Class University. Diperbaiki dengan menggunakan standar baru untuk mencapai world class university. Malcolm Baldrige merupakan audit mutu berstandar International yang siap untuk melawan perubahan zaman. Malcolm baldrige mengembangkan pendekatan (approach) yang fleksibel dan kreatif selaras dengan kebutuhan organisasinya khususnya Perguruan Tinggi Keagamaan Islam Negeri.
\end{abstract}

Kata Kunci: Peningkatan mutu, Lembaga Pendidikan, Malcolm Baldrige criteria 


\section{INTRODUCTION}

Education is a foundation as well as an important pillar that is expected to bring about change (transfiguration) of a nation (Zamroni, 2017). The world of education is not always only a means or media for improving the quality of human resources, but also a very urgent vehicle for changing the mindset of society (civil society) through a learning process that is managed effectively based on management standards and generally applies both at the level of education (Dakir \& Elbadiansyah, 2011) at the national level as well as at a broader level, namely international. Education that focuses on quality is education that develops various programs and services to ensure the needs of its main users, namely students and society. The community at large is a graduate user consisting of the business world, further education institutions, the government and the wider community, including the creation of independent businesses by graduates. Quality must be the main driver for product and service excellence (Amir, 2019). Quality First must be the paradigm of every person involved in business and educational activities (Amin, Siswanto, \& Hakim, 2018). Various Indonesian laws regulate curricula whose development must pay attention to increasing faith and piety, the demands of the world of work, and the dynamics of global development required by graduates of the world of education.

In line with the spirit of continuous improvement and evaluation, currently there is one criterion that is quite popular to be used at the international level, namely the Malcolm Baldrige Education Criteria for Performance Excellence (MBECfPE). MBCfPE is a criterion that can be used in conducting a program audit (Cazzell \& Ulmer, 2009). The use of Baldrige criteria (Leadership, Strategy, customer, Measurement, analysis, and knowledge management, workforce, operations, and results) as a management system and superior performance measurement tools has spread to various countries including Indonesia. Initially this criterion was applied to the business world, especially manufacturing. Entering 2001 the Baldrige National Quality Program introduced a new criterion, specifically for the field of education, which was named the Baldrige Education Criteria for Performance Excellence. Until 2008 Malcolm Baldrige Education Criteria for Performance Excellence (MBECfPE) has been used as a criterion by more than 45 states in the USA and 45 countries in the world (Zakhiroh, 2014).

Several researchers have conducted research on this Malcolm Baldrige Criteria. Hesty in his research explained that leadership is positively correlated with the work environment of lecturers using the Malcolm Baldrige criteria. The more effective the leadership, the better the work environment. Age and tenure do not correlate with leadership, work commitment and work environment (Widyasih, Hesty, 2012). Then Rufqotuz explained the principal's ability to integrate the Baldrige with the existing quality management system in schools, namely the National Education Standards and the International Organization for Standardization (ISO) and from the focus of the workforce, schools were able to build a conducive workforce environment and achieve high performance (Zakhiroh, 2014). 
The Malcolm Baldrige criterion has a positive influence on the culture of accepted quality. Based on the elasticity test, the leadership variable has a relatively dominant influence on the quality culture. In their services, employees prioritize satisfaction for students and student guardians so that harmony is established between employees and stakeholders to improve the quality of school education (Dakir \& Fauzi, 2020).

UIN Sunan Kalijaga is an Islamic University located in Yogyakarta. As one of the State Islamic universities, it has a vision to achieve a world class university (world class university). The accreditation of this university is A in accordance with the stipulations of BAN-PT (National Board of Higher Education) and several AUN-QA accredited study programs, but several aspects must be considered before reaching a world class university. One of the criteria that must be achieved and several requirements that must be fulfilled depends on the external quality program run by international organizations, one of which is the Malcolm Baldrige Criteria. Baldrige is a guide as well as a comprehensive / comprehensive performance measurement and management guide in improving and guiding organizational performance to achieve the excellence and best quality expected. In the category of educational services related to the demands of stakeholders, educational institutions are expected to be able to carry out a learning process that can produce graduates who have excellence and competence with national and international standards. For this reason, it is very necessary to improve the performance of education providers as a whole so that increased excellence and competitiveness can be achieved. The focus of this research is to analyze the opportunities for using the Malcolm Baldrige criteria to be used as a benchmark for improving PTKIN throughout Indonesia.

\section{RESEARCH METHODS}

The method that researchers use in this research is a qualitative type of case study. The qualitative research method is a scientific research approach that aims to understand social phenomena that prioritize the process of communication and deep interaction between researchers and the phenomena under study (Sugiyono, 2017). Thus, in qualitative research the researcher becomes the source of the instrument, namely the direct data collector. This research is a descriptive analysis, in which data collection is done through observation, interview and documentation. The researcher then conducts an analysis of something that is being sought until the research is declared complete. This study tries to dig up various information related to the Malcolm Baldrige criteria for education by making observations (previous research data), interviews (various elements of both the education management lecturers and the LPM section of the UIN Sunan Kalijaga). The researcher attempts to find opportunities to use Malcolm Baldrige as a tool to reach the world class university. This research was conducted so that Islamic universities not only use a national class quality assurance system, but also an international class. There appears new knowledge that the use of the Malcolm Baldrige criteria is not only for company and industry classes, but also for educational institutions. 


\section{RESULTS AND DISCUSSION \\ Malcolm Baldrige Criteria}

Malcolm Baldrige Criteria is a formal or officially recognized quality management system or program in effect in the United States, first created at the US Congress in 1987 as a tribute to Malcolm Baldrige, Commerce Department Secretary (Machali \& Hidayat, 2016). Baldrige himself was the minister of trade of the United States (1981-1987) in the era of President Ronald Reagan who had a major contribution to improving quality in various longterm aspects in the United States (Widyasih, Hesty, 2012). Baldrige strongly supports quality management as a key to the prosperity and welfare of the country and as a long-term strength. Baldrige is the one who makes the initial concept or basis of quality control. Every year Malcolm Baldrige gives an Award to an organization that implements the Malcolm Baldrige Criteria for an existing performance excellence in the company (Curkovic, Melnyk, Calantone, \& Handfield, 2000). This award is administered and regulated by the National Institute of Standards and Technology (The National Institute of Standards and Technology). The Baldrige framework in its implementation can help manage all organizational components as a unified whole, so that organizational plans, processes and actions can be consistent. The system building blocks are the Baldrige criteria for Performance Excellence, core values and concepts, and assessment guidelines (Amalia, Adrianto, \& Harrani, 2008).

Baldrige promotes a systems perspective which means managing all components of the organization as a whole to achieve sustainable success. The system building blocks and the integration mechanism are core values and concepts, the seven categories which are interrelated with the assessment guidelines. Baldrige has national and global impacts so that the Baldrige framework and criteria can play three roles in strengthening competitiveness. First, it helps improve the capabilities and performance of the organization. Second, providing communication facilities for various information and communication on best practices among educational organizations and other types of organizations. Third, maintaining the progress and development of partnerships involving schools or educational institutions, industry and other organizations. Fourth, serving as a work tool to understand and understand and improve organizational performance, and guide in planning and training and organizational guidance.

The Baldrige framework and the seven (7) criteria contained in the Malcolm Baldrige are used to help organizations improve competitiveness. The Baldrige pattern approach has been widely used by thousands of organizations to stay afloat in competitive conditions by increasing effectiveness (Beard \& Humphrey, 2014).

\section{Malcolm Baldrige Criteria for Education}

Malcolm Baldrige is a method used to improve overall organizational performance. Malcolm Baldrige can also play an active role in improving performance continuously by using a measurement and providing feedback in the performance of the organization. Based on an interview with Dr. Suwadi (Lecturer in Education Management at UIN Sunan Kalijaga) explained that the 
Malcolm Baldrige Criteria for Education can be used as a guideline for educational institutions in developing the quality of existing human resources. Human resource development itself cannot be separated from school performance and the management of the school itself. In terms of improving the quality of an organization (Baharun, 2016). Malcolm Baldrige has 7 criteria that can be used in the framework of an integrated approach in all areas of management (Taufik, 2013).

\section{Leadership (120)}

The leadership category is the leader's actions and guides the educational organization's performance in self-defense. This criterion examines how principals pay attention to the values and expectations of school performance that focus on students and stakeholders, learning, empowerment, innovation, learning and school direction. This criterion also examines how the school and the direction of the school pay attention to its responsibilities to the community and its main community supporters a) Organizational leadership (70 points): Setting direction and strategy, management, reviewing organizational performance, 2) Public responsibility and citizenship (50 points): Ethical behavior, environmental support (community)(Anastasiadou \& Taraza, 2019).

\section{Strategy (85)}

This category develops strategic objectives and implementation plans, implements and modifies them as circumstances require, and measures progress. This category emphasizes that the long-term success of the organization and the competitive environment are major strategic issues that need to be an integral part of overall planning. Making decisions about the core competencies of an organization and work systems is integral to ensuring the present and future success of an organization, and therefore these decisions are strategic decisions. This criterion examines the school's strategy development process, including how the school can develop strategic goals, important action plans, and how the plan is disseminated and how performance is researched, a) Strategy development (45 points): The process of making strategies and strategic objectives, b ) Dissemination of the strategy (40 points) Dissemination and projected performance.

\section{Customers (85)}

This category engages students and other customers for long-term educational success, including how to listen to the voice of customers, serve the expectations of students and other customers, and build good relationships with students and other customers. This category emphasizes customer engagement as an important outcome of learning and overall strategy performance excellence. Results for students and other customer satisfaction and dissatisfaction provide important information for understanding students, other customers, and the market. In many cases, the voice of the customer provides meaningful information not only to students and other customers but also that their actions can contribute to organizational behavior to be successful 
today and in the future. This criterion examines how the school determines the needs, expectations and preferences of students and their stakeholders. This criterion also examines how a school builds relationships with students and stakeholders and how to determine their satisfaction, a) Knowledge of stakeholder needs and wants (40 points), b) Relationship between student and stakeholder satisfaction (45 points): relationship building and determination of stakeholder satisfaction.

\section{Measurement, analysis, and knowledge management (90)}

In simple terms, category 4 is the "brain center" for alignment between implementation and strategic objectives, a) Measurement of organizational performance (45 points), b) Analysis of organizational performance (45 points): availability of data, information and organizational knowledge.

\section{Workforce (85)}

This category discusses the key practices of a workforce that is geared towards creating and maintaining a high performance environment and an engaged workforce to activate it and the organization by adapting to change so as to obtain maximum results. In order to strengthen the alignment of basic workforce management with the overall strategy, the Education Criteria also include workforce planning as part of overall strategic planning. This criterion examines how schools enable teachers and staff to develop and use their full potential in line with school goals. These criteria also test the efforts of schools to build and maintain a work environment that is conducive to performance excellence, full participation and personal and school growth, a) Work systems (35 points): organization, job management, employee performance management systems, recruitment and levels. career, b) Employee motivation and learning (25 points): education, training and career development, and c) employee satisfaction and welfare ( 25 points): work environment, benefits and facilities.

\section{Operations (85)}

Categories centered on organizational performance, educational programs and services, innovation, and operational effectiveness to achieve present and future organizational success. This criterion examines the main aspects of the management process of a school, including educational design that focuses on learning, support and a partnership process that involves all work units, a) educational design (55 points), b) educational process support (15 points), c) partnership process (15 points).

\section{Results (450)}

The categories focus on all the outcomes necessary to sustain an educational organization, student learning outcomes and key processes, student and other customer focused outcomes, work outcomes, leadership outcomes and coordination systems, and overall budget, finance, and marketing performance. The focus of this system maintains the goal of the Baldrige Excellence value. The framework is visible to students, other customers, and the market, superior organizational performance as reflected in student learning and operational indicators and organizational learning and learning by 
members of the workforce. Describe the results related to teachers and school staff ranging from welfare, satisfaction, development of teacher and staff performance systems, a) Performance results (200 points), b) Student and Stakeholder results (70 points), c) Violation and financial results ( 40 points), d) School and staff results (70 points), e) Effectiveness of organizational results (70 points).

Kuspijani and Sudarso stated that of the 7 criteria for baldrige, each criterion is related to one another. Malcolm Baldrige's Core Values and Concepts. The values and core of Malcolm Baldrige that are trying to build so that an educational institution continues to develop, namely Systems perspective, Visionary leadership, Student-centered excellence, Valuing people, Organizational learning and agility, Focus on success, Managing for innovation, Management by fact, Societal responsibility and Ethics and transparency, as well as Delivering value and results (Lee, Rho, \& Lee, 2003).

\section{Division of Malcolm Baldrige Categories}

In Malcolm Baldrige, there are several thresholds that become benchmarks, this measure is called the level and the Baldrige score, the criteria are divided into excellent, average, and poor (Lee, Zuckweiler, \& Trimi, 2006).

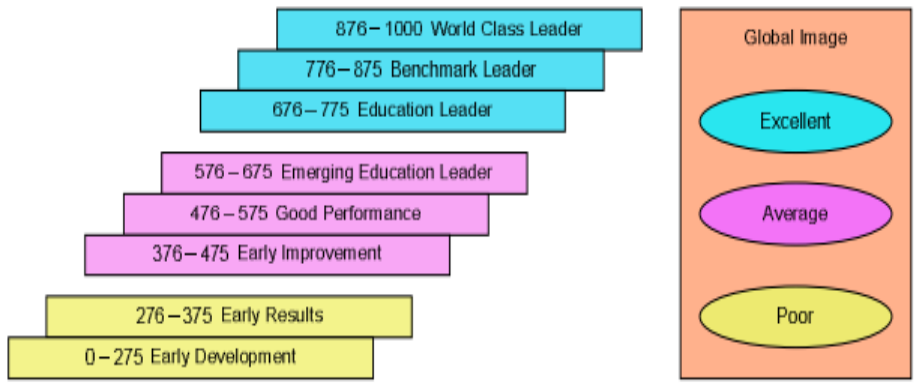

Figure 1 : Baldrige Level and Score Criteria (Singgih, 2017)

Figure 1. It shows the level divided into three global images, Excellent, average, and poor. Then Poor is divided into two, early development and early results. Average is divided into three, early improvement, good performance, and emerging education leaders. Excellent is divided into three, education leader, benchmark leader, and world class universityBased on observations, after scoring an educational institution is done, improvements will be made as seen from some of the shortcomings that the educational institution has. From the information and data obtained, we can see that to become a World Class University, an institution or organization or college must achieve a minimum score of 876 .

\section{Analysis of opportunities for PTKIN to reach World Class University}

The researcher's analysis is presented in the form of a TQM operational table in UIN Sunan Kalijaga to reach a world class university. 
Table 1 : TQM Operational in UIN Sunan Kalijaga

\begin{tabular}{|c|c|}
\hline Element & Standards and Implementation \\
\hline Setting Standard & $\begin{array}{l}\text { Based on the Regulation of the National Accreditation } \\
\text { Board for Higher Education (BAN-PT) Number } 4 \text { of } 2017 \\
\text { concerning the Policy for the Preparation of Accreditation } \\
\text { Instruments, the } 24 \text { national standards for higher education } \\
\text { have been compiled into a system consisting of nine (9) } \\
\text { elements following categories: Category 1: Vision, mission, } \\
\text { goals and strategies, Category 2: Governance and } \\
\text { cooperation, Category 3: Students, Category 4: Human } \\
\text { Resources, Category 5: Finance, Facilities and } \\
\text { Infrastructure, Category 6: Education,Category 7: Research, } \\
\text { Category 8: Community Service, Category 9: Outcomes and } \\
\text { Outcomes: results of education, research and community } \\
\text { service. And also using the AUN-QA Standard for Asian } \\
\text { standards. }\end{array}$ \\
\hline $\begin{array}{l}\text { Monitoring } \\
\text { Performance }\end{array}$ & $\begin{array}{l}\text { UIN Sunan Kalijaga is proven to carry out all of the above } \\
\text { standards because the accredited institution is "A" with a } \\
\text { score of } 367 \text { which was previously } 361 \text {. It was detected that } \\
34 \text { out of } 55 \text { Study Programs were Accredited "A", } 6 \text { out of } \\
55 \text { International Accredited Study Programs. Actually, in } \\
\text { terms of opportunity, we have it, but because there are still } \\
\text { many assumptions that national accreditation has met these } \\
\text { criteria, there are still many. Then it is reviewed in terms of } \\
\text { the cost of the International accreditation. The analysis can } \\
\text { be presented in the form of TQM operational data in UIN } \\
\text { Sunan Kalijaga. }\end{array}$ \\
\hline $\begin{array}{l}\text { Correcting for } \\
\text { deviation }\end{array}$ & $\begin{array}{l}\text { Because if the institution or institution of higher education } \\
\text { ONLY relies on the standard of assessment and evaluation } \\
\text { carried out by BAN PT which includes nine (9) criteria / } \\
\text { categories / standards, even though the higher education } \\
\text { institution or educational institution has obtained } \\
\text { accreditation A (the highest score), but if it is measured or } \\
\text { assessed by international standards EdPEx may only get a } \\
\text { score in the interval } 476 \text { - 575, so that internationally it may } \\
\text { be categorized as Good Performance University only has } \\
\text { NOT reached World Class University. Improved by using a } \\
\text { new standard to reach a world class university. }\end{array}$ \\
\hline New Standard & $\begin{array}{l}\text { The new standard is set using the Malcolm Baldrige For } \\
\text { Performance Education Excellence criteria listed in } \\
\text { appendix I (1000 Malcolm Baldrige Instrument). Using } 7 \\
\text { standards of Leadership (120), Strategy (85), Customer (85). } \\
\text { analysis, Measurement, and knowledge management (90), }\end{array}$ \\
\hline
\end{tabular}




\begin{tabular}{|l|l|}
\hline Workforce (85). Operation (85), Results (450), Total 1000. \\
From this data, we can see that when a university wants to \\
become a World Class University, the higher education \\
organization or institution must achieve a minimum score \\
of 876. If the universities and various educational \\
institutions in Indonesia wants to compete and compete to \\
achieve world-class universities, so it should use guidelines \\
or guidelines or so-called road maps from EdPEx or this \\
international standard, NOT using national standards from \\
BAN PT which is the goal or goal is to become an \\
institution. best nationally in Indonesia is NOT a world- \\
class university or international standard. Based on this, \\
EdPEx can complement the national Accreditation \\
Standards.
\end{tabular}

Table 1. It shows that the achievement of a world class university must be pursued through the path of total operational quality management by taking into account several elements that become the benchmarks for the use of new standardsTowards a World Class University Using the Malcolm Baldrige Criteria for Performance Excellence (EdPEx) version of the Education Performance Excellence (MBCfPE) Standard. Based on information, from 2018 to 2020 onwards the accreditation of Indonesian higher education institutions will use the following some standards: National Education Standards, National Research Standards, and National Community Service Standards: standards of community service results, community service content standards, community service process standards, community service assessment standards, community service implementation standards, community service facilities and infrastructure standards, community service management standards community, funding standards and community service financing.

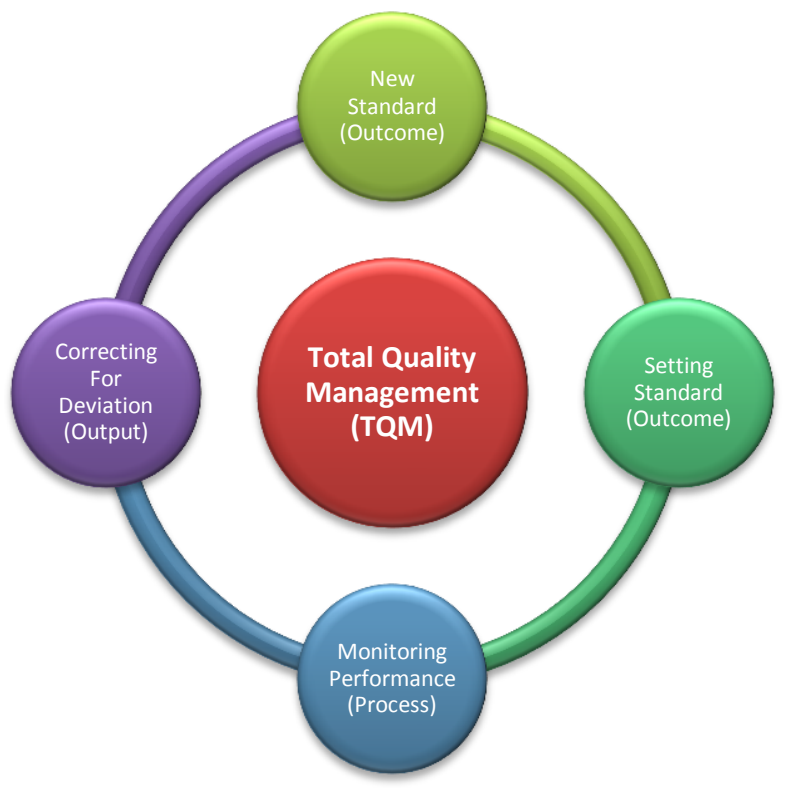

Figure 2 : Operational Management in TQM 
Figure 2 shows that operationally, integrated quality management is operated based on standard settings, performance monitoring, correcting for deviation, and new standards. First, standard setting is the standard setting of a program in running an organization to achieve its goals. Second, performance monitoring is checking the implementation of standards, in this case the question usually arises whether the implementation is in accordance with the established standards. Third, Correcting for deviation is the discovery of a deviation that is not in accordance with the standard or the need for standard improvement, then fourth, new standards, namely determining new standards to achieve the program, either replacing or adding old standards. All the operational elements of the TQM are carried out sequentially and systematically.

This is a golden opportunity for universities wishing to compete internationally (global market) to adopt Education Performance Excellence (EdPEx), so that in addition to the higher education institutions, they will obtain national standards for institutions with A accreditation, as well as obtain international standards to become World Class University. which has a minimum score of 876 . So that internationally it may even be categorized as a Good Performance University, it has NOT reached World Class University.

Universities in the USA and other developed countries generally use EdPEx (Education Performance Excellence) as a competitive standard or a standard to compete in their international level. EdPEx 2017-2018 has been compiled by Vincent Gaspersz in a short book on Guidelines for Implementing Education Performance Excellence Based on MBCfPE 2017-2018 for Educational Organizations. The following is the framework for building EdPEx 2017-2018 to achieve World Class University in accordance with the Motto of UIN Sunan Kalijaga.

Some time ago, Universitas Airlangga was audited by the British Standard Institution (BSI) as an auditor. The audit, which was conducted for 5 days (23-27 November 2015), came out today, Friday (11/12). The results of the audit stated that UNAIR was ISO and IWA-2 certified, and received a Malcolm Baldrige score of 703, which was included in the excellent level category. This score has increased compared to last year. Last year UNAIR got a Malcolm Baldrige score of 691.4, which put UNAIR in the category of industry leader.

The Chancellor hopes that this achievement will support UNAIR's international position, as Kemenristek Dikti targets UNAIR to become the world's 500 best universities by 2019. In line with the Chancellor, Head of UNAIR Quality Assurance Agency (BPM), Unggul Heriqbaldi said that the score is not the goal. Through an audit, his party wants to ascertain whether the university management system is running well and is continuously being improved. These continuous improvements have resulted in better UNAIR performance and scores. From UNAIR data it was detected that 117 out of 166 "A" Accredited Study Programs, 6 International Accredited, 14 will be ASIC Accredited. Obtained 703 out of 1000 in Malcolm Baldrige criteria.

If we discuss one of Indonesia's oldest PTKIN, namely UIN Sunan Kalijaga, it is detected that 34 of the 55 Study Programs are Accredited "A", 6 
out of 55 Study Programs are Internationally Accredited. Actually, in terms of opportunity, we have it, but because there are still many assumptions that national accreditation has met these criteria, there are still many. Then it is reviewed in terms of the cost of the International accreditation.

\section{CONCLUSION}

Looking at Indonesia which emphasizes quality education in every lesson, management, leadership and so forth, it has a very basic thing that should be a benchmark for the development of the quality of education. However, all of this does not have to be carried out just the way it is without values being implanted and a strategy that is carried out systematically.

With the times, educational institutions continue to compete nationally and globally in order to continue to exist. To ensure that education is always in its corridor, the quality assurance system is tasked with measuring success and measuring the achievement of national education standards. So accreditation is always held to test the feasibility of an educational institution. BAN is a national body formed by the government to carry out a due diligence on educational institutions. It is considered insufficient to be said to be appropriate according to international standards. Various quality audits such as Malcolm Baldrige are international standard quality audits that are ready to fight the changing times. Malcolm Baldrige develops creative and flexible approaches in line with organizational needs. The suggestion for the next researchers is to continue to do research in the field of quality through Malcolm Baldrige, because the researcher is aware of their finesse. Thus, the researcher expects other researchers to research from other perspectives as well in that there are several other international quality guarantors.

\section{REFERENCES}

Amalia, A. B., Adrianto, D., \& Harrani, K. (2008). Analisis Perbandingan Penghargaan Kualitas Malcolm Baldrige National Quality Award dengan European Quality Award (MBNQA vs EQA). J@Ti Undip: Jurnal Teknik Industri, 3(2), 131-141.

Amin, N., Siswanto, F., \& Hakim, L. (2018). Membangun Budaya Mutu yang Unggul dalam Organisasi Lembaga Pendidikan Islam. Al-Tanzim: Jurnal Manajemen Pendidikan Islam, 2(1), 80-93.

Amir. (2019). Membangun Budaya Mutu pada Lembaga Pendidikan Islam Menuju Madrasah Unggul. Al-Tanzim: Jurnal Manajemen Pendidikan Islam, 3(2), 1-12. https://doi.org/10.33650/al-tanzim.v3i2.676

Anastasiadou, S., \& Taraza, E. (2019). The Structure and Paths of Malcolm Baldrige National Quality Award (MBNQA) Dimensions Applied in Greek Tertiary Education System. Proceedings of EDULEARN19, 1(3), 455463. 
Baharun, H. (2016). Management of Quality Education in Pesantren: The study of The Education Quality Improvement Pesantren by Strategy Management Approach. 2nd International Conferences on Education and Training (ICET), 695-702. Retrieved from http://icet.fip.um.ac.id/wpcontent/uploads/2017/06/PROCEEDINGS-2ND-ICET-BOOK-2-.pdf

Beard, D. F., \& Humphrey, R. L. (2014). Alignment of University Information Technology Resources with The Malcolm Baldrige Results Criteria for Performance Excellence in Education: A Balanced Scorecard Approach. Journal of Education for Business, 89(7), 382-388. https://doi.org/10.1080/08832323.2014.916649

Cazzell, B., \& Ulmer, J. M. (2009). Measuring Excellence: A closer Look at Malcolm Baldrige National Quality Award Winners in The Manufacturing Category. Journal of Technology Management and Innovation, 4(1), 134-142. https://doi.org/10.4067/S071827242009000100012

Curkovic, S., Melnyk, S., Calantone, R., \& Handfield, R. (2000). Validating the Malcolm Baldrige National Quality Award Framework through Structural Equation Modelling. International Journal of Production Research, 38(4), 765-791. https://doi.org/10.1080/002075400189149

Dakir, \& Elbadiansyah. (2011). Mutu Pendidikan pada Perguruan Tinggi Keagamaan: Dari Manajemen Kelembagaan hingga Konstruksi Kurikulum Interrelasi. MUADDIB: Studi Kependidikan dan Keislaman, 7(1), 47-66. https://doi.org/10.24269/muaddib.v7n1.2017.47-66

Dakir, \& Fauzi, A. (2020). Manajemen Mutu Pendidikan Islam Terpadu; Strategi Pengelolaan Mutu Madrasah dan Sekolah di Era Revolusi Industri 4.0. Yogyakarta: Pustaka Pelajar.

Lee, S. M., Rho, B. H., \& Lee, S. G. (2003). Impact of Malcolm Baldrige National Quality Award Criteria on Organizational Quality Performance. International Journal of Production Research, 41(9), 2003-2020. https://doi.org/10.1080/0020754031000077329

Lee, S. M., Zuckweiler, K. M., \& Trimi, S. (2006). Modernization of the Malcolm Baldrige National Quality Award. International Journal of Production Research, 44(23), 5089-5106. https:// doi.org/10.1080/00207540500161043

Machali, I., \& Hidayat, A. (2016). The Handobook of Education Management: Teori dan Praktek Pengelolaan Sekolah/Madrasah di Indonesia. Jakarta: Prenadamedia Group.

Singgih, M. L. (2017). Penilaian Kinerja Suatu Jurusan dengan Kriteria Malcolm Baldrige National Quality Award dan Penentuan Ranking menggunakan Analytic Network Process. Jurnal Department Of Industrial Engineering Institut Teknologi Sepuluh Nopember, 2(3), 1-11.

Sugiyono. (2017). Metode Penelitian Kuantitatif, Kualitatif, dan RED. Bandung: Alfabeta.

Taufik, I. (2013). Pengukuran Kinerja Institusi Pendidikan Berdasarkan Kriteria Malcolm Baldrige Nasional Quality Award di SMP Muhammadiyah 1 Gresik. Universitas Muhammadiyah Gresik. 
Widyasih, Hesty, M. S. D. F. F. (2012). Wirakusumah Korelasi Kepemimpinan dengan Komitmen dan Lingkungan Kerja Dosen Berdasarkan Kriteria Malcolm Baldrige (Suatu Survei Eksplanatori pada Dosen Program Studi D3 Kebidanan di Propinsi Daerah Istimewa Yogyakarta). Jurnal Orasi Bisnis, 8(1), 61-68.

Zakhiroh, R. (2014). Implementasi Kebijakan Sekolah dalam Penerapan Malcolm Baldrige Education Criteria for Performance Excellence di SD Muhammadiyah 2 Gresik. Jurnal Kebijakan Dan Pengembangan Pendidikan, 2(1), 64-71.

Zamroni. (2017). Manajemen Mutu Pendidikan: Ikhtiar dalam Meningkatkan Mutu Pendidikan Madrasah melalui Pendekatan Balanced Scorecard. Tulungagung: Akademia Pustaka. 